REGULAR ARTICLE

\title{
THE IMPACT OF SUPPORT POLICIES ON TECHNICAL EFFICIENCY OF FARMS IN KOSOVO
}

\author{
Anera ALISHANI
}

\author{
Address: \\ University Ukshin Hoti in Prizren, Faculty of Economics, Department of Business Administration, Prizren, Kosovo \\ E-mail: anera.alishani@gmail.com
}

\begin{abstract}
The effects of support policies on technical efficiency are not clear and are very complex because the results may be either positive or negative. The effects can be positive if the money received will serve as an incentive to innovate or to switch to new technologies or can have a negative effect if the money received increase the income of the farms and as a result prefer to have more leisure time. Given the theoretical uncertainty of the impact of supporting policies on efficiency, productivity and added value, the aim of this paper is to address this issue empirically. This paper contributes to the literature for the case of Kosovo by fulfilling the following objectives (i) to measure technical efficiency of farms in Kosovo and (ii) to identify the effect of subsidies by employing a stochastic output distance function and an inefficiency effect model as the one proposed by Battese and Coelli (1995). Parametric stochastic frontier approach was employed to estimate technical efficiency and to determine the effect of exogenous variables on technical efficiency through one-step approach. The share of total subsidies to total output (\%) was used as proxy for policy variable and a set of farm characteristics as exogenous variables. We used FADN of Kosovo data provided by MAFRED for 2014. The results suggest that on average a farm in Kosovo produced $15.7 \%$ of the maximum output, while the rest of the potential output was lost due to technical inefficiency. Subsidies had negative effect on technical efficiency, however insignificant.
\end{abstract}

Keywords: farm performance, technical efficiency, SFA, subsidies, Kosovo JEL: R15, Q18, Q12, R28

\section{INTRODUCTION}

In the economy of Kosovo, agriculture plays a very important role and has a positive impact on the quality of life and on the sustainable development of the rural areas considering that $60 \%$ of population live in rural areas and its contribution to GDP is $10.5 \%$. In addition, there are 130,775 agricultural holdings which occupy 413,635 ha of land for agricultural purposes and employ 362,700 persons or approximately $20.5 \%$ of total population as of 2014 (KAS, 2014). Although it may be thought that this contribution of agriculture to the economy is volatile, on the other hand, it is suggested that Kosovo has the potential to compete in different subsectors of agriculture, especially in the livestock and cash crop subsectors. Due to this importance, the Kosovo Government has assured to further increase the budget for the development of the agricultural sector by increasing support for sectors with comparative advantages such as the crop and livestock sectors. The actual budgetary support for agriculture and rural areas has increased from $€ 11$ million in 2010 to $€ 27.0$ million in 2014 and to $€ 59.1$ million in 2015. Compared to 2010, in 2014 the budget support for agriculture has increased for $145 \%$ and in 2015 for $437 \%$ (KerolliMustafa and Gjokaj, 2016).

On the other hand, subsidies are a major part of every nation's budget. A large part of almost every nation's income is headed for agricultural subsidies. Subsidies are intended for the protection of the domestic agriculture
(Koo and Kennedy, 2006), are used as accelerator of the growth of agricultural sector and are important for international trade (Swain, 2009; Vozarova and Kotulic, 2016). In agriculture, subsides are paid to the farmers to supplement their incomes, to manage the supply of agricultural products and also to influence the cost and supply of such product in international markets (Swain, 2009).

For the case of Kosovo, the Ministry for Agriculture, Fishery and Rural Development (MAFRED) since 2008 has started to support farmers with subsidies and grants through direct payments and the rural development programme. The planned budget for Direct Payments increased from $€ 14$ million in 2014 to $€ 23$ million in 2015 (MAFRD, 2015, 2016). Even though the planed budget for direct support in 2014 was $€ 14$ million, there were spent $€ 15.3$ million. In 2015 , $€ 21.4$ million were distributed to farmers in the form of direct payments which compared to the previous year marked an increase of 40\% (MAFRD, 2016). Also in 2016, the total support through direct payments exceeded the planned budget which was $€ 23$ million to $€ 26.1$ million (MAFRD, 2017). Compared to the previous year, the support through direct payments increased by $22 \%$ (MAFRD, 2017). However, the empirical analysis would provide clearer information regarding the direction and the significance of the effect of subsidies on the performance of the farm.

Different papers consider different indicators for measuring the performance of the agricultural sector. 
Efficiency is an important indicator for performance measurement. Efficiency can be distinguished into technical and allocation efficiency. Technical efficiency represents the capacity of an entity to produce the maximum output from a quantity of inputs subject to the available technology (Koopmans, 1951). Allocation efficiency refers to the ability to choose optimum input levels for given factor prices. When adding both the technical and the allocation efficiency, we generate the economic efficiency. Assuming that inputs are exogenously given, one may not address allocation inefficiency simply because the input allocation problem is assumed away. By contrast, if inputs are endogenous, then allocation decisions using some economic behaviour have to be made (Kumbhakar, Wang, and Horncastle, 2015). Because in this study we treat the inputs as exogenous, then the focus of this paper is on technical efficiency by assuming that there is no allocation inefficiency. (i.e., all the producers are assumed to be allocation efficient).

Factors affecting the technical efficiency of the agricultural sector are numerous, however what is of interest in this paper is to assess the impact of agricultural support policies on technical efficiency. Support policies are considered as one of the most effective mechanisms for increasing the agricultural sector (Swain 2009). Despite the fact that economic theory offers relatively little information on the direction of the relationship between support policies and technical efficiency, it is still possible to find a theoretical background (Latruffe $\boldsymbol{e t}$ al., 2008). According to Bojnec and Latruffe (2009), support policies are one of the main factors that explain the farm's efficiency or even its inefficiency. These support policies can increase the level of technical efficiency if they make the farmers to innovate more or to move to new technologies (Harris and Trainor, 2005), or even lower it if the higher incomes from subsidies cause a lack of efforts and initiatives (Bergström, 2000). In general, the effects of support policy are complex and theoretically unclear. However, they need to be analysed in detail because the farms are supported by the state budget and it is very important to continually analyse the efficiency of money spent on value added (Kroupová and Malý, 2010).

So, the purpose of this paper is to assess the performance of the agricultural sector for the case of Kosovo by measuring technical efficiency and the incorporation of exogenous variables. More specifically, the impact of various factors on technical efficiency of the farms will be studied, paying particular attention to subsidies. The objectives of this research are: (i) to calculate farm level technical efficiency on farms in Kosovo and (ii) to identify important factors causing efficiency differences among the farms in Kosovo by focusing on subsidies.

\section{DATA AND METHODS}

\section{Production frontier model and the inefficiency effect model}

The model to be used in this paper follows the one proposed by Battese and Coelli (1995). This production frontier model allows for simultaneous estimation of technical efficiency and the effect of exogenous variables on technical efficiency (more specifically on technical inefficiency). This is also the reason why this is called as one-step procedure. In this paper, the SFA approach is preferred over nonparametric approach (e.g. DEA) because agriculture is characterized as a stochastic sector, meaning that the unpredictable weather and diseases may influence the production. Also the data from transition economies are generally noisy in comparison to the data from the other countries. In addition, compared to the deterministic approach where all the deviation from the frontier is attributed only to inefficiency, in the stochastic frontier the deviation from the frontier is attributed to inefficiency as well as to random factors such as measurements errors, unspecified variables and even the hazard factors.

The stochastic production frontier model relates the quantity of output $(y)$ of a given farm to a vector of inputs used $\left(X \in R_{+}^{N}\right)$ through the production technology $(f)$ (Eq.1).

$y_{i}=f\left(x_{i}\right) \cdot \exp \left(v_{i}-u_{i}\right)$

Where $v_{i}$ is the two sided noise component with $v_{i} \sim$ iid $N\left(0, \sigma_{v}^{2}\right)$ which means that this component is assumed to be independent and identically distributed normal random variable with zero mean and constant variance and which captures the random effects. On the other side, $u_{i}$ is the non-negative technical inefficiency component with truncated normal distribution with different mean and variance among farms $u_{i} \sim N^{+}\left(\mu_{i}, \sigma_{i}^{2}\right)$ and which captures technical inefficiency effects.

Technical efficiency is calculated as (Kumbhakar and Lovell, 2000) (Eq. 2).

$T E_{i}=\exp \left(-u_{i}\right)$

On the other hand, there is a set of various factors, also known as exogenous variables or explanatory variables that can explain the technical efficiency differences among farms (Zhu, Demeter, and Lansink, 2008). These variables are known as exogenous because they neither are used as inputs in the production process such as labour, capital and land nor are as output of the farm but still influence the degree of technical inefficiency and hence the performance of the farm. As a result, they are incorporated in the inefficiency term such as in the model of Kumbhakar et al. (1991) and Battese and Coelli (1995).

The exogenous variables are denoted as $z \in R^{J}$ (Battese and Coelli, 1995) which can be indexed by $p, p=$ $1,2, \ldots . . J$. Technical inefficiency model $\left(u_{i}\right)$ is defined by Eq. 3.

$u_{i}=z_{i} \delta+w_{i}$

where $z_{i}$ is the vector of firm-specific $J$ variables, $\delta$ is the unknown vector of $J$ parameters to be estimated, and the error term $w_{i} \sim N\left(0, \sigma_{w}^{2}\right)$ is truncated from below by the 
variable truncated point $-z_{i} \delta$.

The production frontier model and the inefficiency effect model can be estimated simultaneously and this one-step procedures allows that in the same time to be estimated the efficiency scores and the factors that determine technical efficiency. According to Zhu et al. (2008), the production frontier model and the inefficiency effect model can be defined as Eq. 4.

$T E_{i}=\exp \left(-u_{i}\right)=\exp \left\{-z_{i} \delta-w_{i}\right\}$

Many authors (Kalirajan, 1991; Ray, 1988) use the two-step procedure to estimate the effect of subsidies on farm performance, however, other authors (Kumbhakar et al., 1991; Battese and Coelli, 1995) challenge this approach by arguing that subsidies and other firm-specific factors should be incorporated directly in the estimation of the production frontier because such factors may have a direct impact on productivity and efficiency.

As in many other papers, also in this paper, will be employed the Battese and Coelli (1995) model of the stochastic production frontier which estimates the technical efficiency and which in the same time allows for the inclusion of explanatory variables with a one-stage procedure (Eq. 5-6).

$y_{i}=f\left(x_{i} ; \beta\right)+v_{i}-u_{i}$

$u_{i}=z_{i} \delta+w_{i}(6)$

These models differ from the others because subsidies are allowed to affect output but not also vice-versa and can be estimated jointly.

\section{Parametric Approach}

One of the primary task, when estimating the stochastic frontier model, is to determine the functional form of the production frontier. According to Coelli et al. (2005), there exist different functional forms for the production frontier such as Cobb-Douglas, CES, Translog, generalised Leontief, normalised quadratic and its variants. It is recommended to estimate the production frontiers according to a number of alternatives and then to select a preferred model using the likelihood ratio test (Coelli, 1996). In addition, in the study of Giannakas $\boldsymbol{e t}$ al. (2003) is suggested the choice of the functional form can affect the estimates of the production structure as well as the measurements of the technical efficiency. In this sense, the choice of an appropriate functional form affects the identification of the factors that determine individual performance. Cobb-Douglas and the Translog functional form are the two the most used forms in the empirical studies of production (Battese and Broca, 1997). More specifically, the production frontier of the $i^{\text {th }}$ farm expressed according to the two functional forms (Eq. 7 8).

Cobb-Douglas frontier model:

$$
\ln y_{i}=\beta_{0}+\sum_{j=1}^{K} \beta_{j} \ln x_{j, i}+v_{i}-u_{i}
$$

Translog frontier model:

$$
\begin{aligned}
& \ln y_{i}=\beta_{0}+\sum_{j=1}^{K} \beta_{j} \ln x_{j, i}+ \\
& \frac{1}{2} \sum_{j=1}^{K} \sum_{h=1}^{K} \beta_{j h} \ln x_{j, i} \ln x_{h, i}+v_{i}-u_{i}
\end{aligned}
$$

where the $\mathrm{u}_{\mathrm{i}}$ also knows as technical inefficiency is expressed according to Eq. 9.

$u_{i}=z_{i} \delta+w_{i}=\delta_{0}+\sum_{m}^{J} \delta_{m} z_{m i}+w_{i}$

the subscript $i=1,2, \ldots ., \mathrm{n}$ stands for farms; $j, k=1,2, \ldots ., \mathrm{J}$ stands for inputs while $m=1,2, \ldots, \mathrm{M}$ stands for farmspecific efficiency related variables.

In this regard, it is firstly required to test which of these specifications best represent the data by considering that the SFA accommodates both production functions. For this purpose, is needed to test firstly the adequacy of the Cobb-Douglas production function relative to Translog productions function, otherwise known as a less restrictive model. The null hypothesis to test for the functional form, states that all the interaction terms and the square specifications in the translog functional form are equal to zero (Null Hypothesis: $\beta_{i j}=0$ ). The alternative hypothesis states that the translog terms are not equal to zero (Alternative Hypothesis: $\beta_{i j} \neq 0$ )

$\mathrm{H}_{0}$ : Cobb-Douglas is the appropriate functional form.

$\mathrm{H}_{1}$ : Cobb-Douglas is not the appropriate functional form.

Considering that both of the models are nested we have to test the Cobb-Douglas (restricted model) against the Translog specification (unrestricted model) based on the value of likelihood ratio (LR) statistics. If the null hypothesis $\left(\mathrm{H}_{0}\right)$ is not rejected, it means that the CobbDouglas functional form is more appropriate for our productions frontier estimation and it will take the form of Eq. 10.

$$
\begin{aligned}
& \operatorname{lny}_{i}=\beta_{0}+\beta_{1} \text { lnCapital }_{i}+\beta_{2} \text { lnLabour }_{i}+ \\
& \beta_{3} \text { lnLand }_{i}+\beta_{4} \text { lnIntermediateCon }_{i}+v_{i}+u_{i}
\end{aligned}
$$

Contrary, if the null hypothesis $\left(\mathrm{H}_{0}\right)$ is rejected, it means that the trans-log functional forms should be used in the form of Eq. 13.

$$
\begin{aligned}
& \ln y_{i}=\beta_{0}+\beta_{1} \ln \left(K_{i}\right)+\beta_{2} \ln \left(L_{i}\right)+\beta_{3} \ln \left(H_{i}\right)+ \\
& \beta_{4} \ln \left(V I_{i}\right)+\frac{1}{2}\left(\beta_{5} \ln K^{2}+\beta_{6} \ln L^{2}+\beta_{7} \ln H^{2}+\right. \\
& \left.\beta_{8} \ln V I^{2}\right)+\beta_{9} \ln K_{i} * \ln L_{i}+\beta_{10} \ln K_{i} * \ln H_{i}+\beta_{11} \ln K_{i} * \\
& \ln V I_{i}+\beta_{12} \ln L_{i} * \ln H_{i}+\beta_{13} \ln L_{i} * \ln V I_{i}+\beta_{14} \ln H_{i} * \\
& \ln V I_{i}+v_{i}+u_{i}
\end{aligned}
$$

The LR statistics can be calculated from the likelihood values of the Cobb Douglas functional form $\left(\mathrm{LLF}_{\mathrm{o}}\right)$ and the Translog functional form $\left(\mathrm{LLF}_{1}\right)$ using this formula: $\lambda=-2\left(\mathrm{LLF}_{0}-\mathrm{LLF}_{1}\right)$. The $\mathrm{LR}$ value is compared with the critical values of $\chi_{R}^{2}$. The critical value depend on the number of degrees of freedom which is equal to the number of restrictions ( $\mathrm{R})$. Degrees of freedom is equal to 10 , number of restriction from the restricted model to the unrestricted model. The condition for the rejection of the null hypothesis is $L R>\chi_{R}^{2}$, for our case is $L R>\chi_{10}^{2}$, $L R>17.670$, at $5 \%$ significance level.

In order to conduct this test, it is needed to firstly run into the STATA the restricted model, the Cobb-Douglas model. In this case the likelihood functional level was 355.31634. For the Translog functional form were created 10 more variables (interaction terms and square terms) and 
after running this specification the likelihood value was 352.78693. When computing the calculation based on the formula above, we get this result: $\lambda=-2\left[\mathrm{LLF}_{0}-\right.$ $\left.L_{L F}\right)=-2[-355.31634-352.78693)=5.055882$. This value is lower than the critical value of $\chi_{10}^{2}$ which is 17.67, and as a result we do not have enough statistical evidence to reject the null hypothesis, indicating that the Cobb-Douglas functional form better fits the data.

The model to be used from further estimations is the Cobb-Douglas model in which the dependent and the independent variables are expressed in natural logarithmic (Eq. 12).

$$
\begin{aligned}
& \text { lnOutput }_{i}=\beta_{0}+\beta_{1} \operatorname{lnCapital}_{\mathrm{i}}+\beta_{2} \ln \text { Labour }_{\mathrm{i}}+ \\
& \beta_{3} \operatorname{lnLand}_{\mathrm{i}}+\beta_{4} \ln \text { IntermediateCon }{ }_{\mathrm{i}}+\mathrm{v}_{\mathrm{i}}+\mathrm{u}_{\mathrm{i}}
\end{aligned}
$$

where the subscript $i(i=1,2, \ldots, \mathrm{n})$ refers to the $i$ th sample farm. In our case as there are 396 farms, then $i$ ranges from 1 to 396 . The dependent variable $(y i)$ represents the total output in value during 2014 for each farmer $i$. Following the dependent variable in the model are also included four independent variables: Capital presents the value of total assets for the $i$ th farm, Labour presents the average working units (AWU), Land presents the total utilized agricultural area (UAA) in ha, and lastly Variable Input is defined as the value of total intermediate consumption.

In addition, the technical inefficiency model is defined according to the following explanatory variables, specified as a linear function of a series of variables, which are included with the aim to capture some farm specific characteristics that are assumed to have an impact on technical efficiency. The model is presented as Eq. 13.

$u_{i}=\delta_{0}+\delta_{1} z_{1 i}+\delta_{2} z_{2 i}+\delta_{3} z_{3 i}+\delta_{4} z_{4 i}+\delta_{5} z_{5 i}+$

$\delta_{6} z_{6 i}+\delta_{7} z_{7 i}+\delta_{8} z_{8 i}+\delta_{9} z_{9 i}+\mathrm{v}_{\mathrm{i}}+\mathrm{u}_{\mathrm{i}}$

By using the STATA software, we estimated: the frontier production function, the inefficiency effect model, the technical efficiency scores for each farm. In order to obtain the estimates, the Maximum Likelihood approach is used in the centre of which lies the choice of the distribution assumption for the random variable $u_{i}$. The $v_{i}$ random variable has the zero-mean normal distribution while for the $u_{i}$ can be assigned different distribution assumptions. The literature has identified many of such distributions. Most often mentioned distributions are the:

- Half-Normal Distribution with

$u_{i} \sim$ i.i.d. $N^{+}\left(0, \sigma_{u}^{2}\right)$ and $v_{i} \sim$ i.i.d. $N\left(0, \sigma_{v}^{2}\right)$,

- Truncated- Normal Distribution

$u_{i} \sim N^{+}\left(\mu, \sigma_{u}^{2}\right)$ and $v_{i} \sim N\left(0, \sigma_{v}^{2}\right)$, and

- Exponential Distribution.

In this paper, the Half-Normal Distribution will be assumed for the $u_{i}$ as the most usual distribution suggested in literature.

However, the analysis of efficiency continues, as the focus of this paper in not only to obtain some efficiency scores but also to know the effect of some firm-specific variables on the efficiency scores. This analysis may help us to know the factors which cause inefficiency. The interest increases even more, when we include also the variables of subsidization. The effect of subsidies on (in) efficiency scores is of high interest not only for researchers but also for the government. For this purpose, we will continue the analysis by allowing the variance of the inefficiency terms to be a function of some $\mathrm{z}$ variables which are also known as inefficiency explanatory variables (Kumbhakar, Wang, and Horncastle, 2015). In order to conduct this analysis, will be employed a onestep procedure, meaning that the parameters in the ML method and the relationship between inefficiency score and the $\mathrm{x}$ variables are estimated in the same time. If a specific $\mathrm{z}$ variable has a positive significant signs, in means that a firm with higher level of that variables tends to have higher level of inefficiency, on contradictory, the variable with the negative sign means that it decreases inefficiency (it is more efficient).

\section{Data}

For the estimation of the production frontier we used Farm Accounting Data Network (FADN) Kosovo data (FADN MAFRD, 2014) available for 394 farms for year 2014. FADN is considered as a consistent database for the estimation of the production frontiers of farms in Kosovo.

These cross-section data of 394 farms in Kosovo were used to estimate the production frontier, to derive their technical efficiency scores and to determine the effect of exogenous variables by focusing on subsidies. The structure of the farms in the sample according to their size and typology is shown in Table 1.

From 62,616 farms that are in Kosovo with Standard Output (SO) greater than $€ 2,000$ per year, in this dataset are included 394 farms of six different typologies and of 5 different economic sizes. Majority of the farms (38\%) are of the lowest economic size $€ 2,000-4,000$ while the farms with the highest economic size are only $8 \%$ of the farms. According to farm typology, most of the farms belong to mixed crops and livestock (40\%) and of specialized grazing livestock $(36 \%)$, followed by specialized field crops $10 \%$, mixed cropping (9\%) and others. Even though the sample represents only $0.6 \%$ of total population, these were the only data available from MAFRD and as a result will be used for analysis.

\section{Definition of Variables}

As defined in literature on farm technical efficiency, there are three main groups of variables employed as determinants of technical efficiency in transition and western economies which are organized in output, inputs and exogenous variables (Brummer 2001, Giannakas $\boldsymbol{e t}$ al. 2001, Mathijs and Vranken 2001, Rezitis et al. 2003, Latruffe et al. 2004). These variables are related with the characteristics of the farm and technology employed, locational and environmental variables characterizing the conditions for farming and human capital variables.

As output variable (Y) we use Total Agricultural Output (the value in EUR of crops, livestock and livestock products and other output). The total output is used as output in many studies such as in: Bojnec and Latruffe (2013), Latruffe and Fogarasi (2009). As input variables (Xs) Labour (AWU), Land (UAA), Capital (value) and Intermediate Consumption (value) are considered. All the input variables (land, labour, capital and intermediate 
consumption) are expected to positively and significantly affect the performance of the farm proxied by technical efficiency (Table 2).

The classical inputs are taken into account when calculating technical efficiency scores, however, technical efficiency should be explained also by using other variables that may be related to the quality of the factors of production, to the environment, or to policy support which also represent the variable of interest.

There exists a large set of exogenous variables $(\mathrm{Zs})$ that influence the mean and the variance of farmefficiency and that could potentially explain the differences of technical efficiency among the farms in the sample. These explanatory variables in the inefficiency model are related with the management strategies of the farm (financial management proxied by the ratio of debts to total assets) with the environment factors (such as location and specialization) structure of the farm (size, labour) as well as with socio-economic factors (public policies proxied by subsidies) (Table 3).

Table 1 Farms in the sample according to their typology and economic size

\begin{tabular}{|c|c|c|c|c|c|c|c|}
\hline \multirow[t]{2}{*}{ Farm Typology } & \multicolumn{5}{|c|}{ Economic Size } & \multirow[t]{2}{*}{ Total } & \multirow{2}{*}{$\begin{array}{l}\text { Participation } \\
(\%)\end{array}$} \\
\hline & $2000-4000$ & $4000-8000$ & $8000-15000$ & $15000-25000$ & $25000-$ & & \\
\hline Specialist field crops & 6 & 12 & 10 & 8 & 11 & 47 & 10 \\
\hline Specialist permanent crops & 1 & 4 & 4 & 1 & & 10 & 2 \\
\hline Specialist grazing livestock & 5 & 23 & 55 & 30 & 10 & 123 & 36 \\
\hline Mixed cropping & 2 & 3 & 5 & 7 & 4 & 21 & 9 \\
\hline Mixed livestock holdings & & 2 & 3 & 1 & 1 & 7 & 4 \\
\hline Mixed crops - livestock & 17 & 61 & 77 & 14 & 15 & 184 & 40 \\
\hline Total & 31 & 105 & 155 & 61 & 42 & 394 & 100 \\
\hline Participation (\%) & 38 & 35 & 14 & 6 & 8 & 100 & \\
\hline
\end{tabular}

Source: FADN MAFRD (2014)

Table 2: Definition of main variables

\begin{tabular}{|c|c|c|c|}
\hline Factor & Definition & $\begin{array}{l}\text { Measurement } \\
\text { Unit }\end{array}$ & $\begin{array}{l}\text { The expected } \\
\text { sign }\end{array}$ \\
\hline Total Output (Y) & $\begin{array}{l}\text { Total of output of crops and crop products, livestock and } \\
\text { livestock products and of other output (SE131) }\end{array}$ & EUR & \\
\hline Capital & Capital, in terms of the value of fixed assets (SE436) & EUR & Positive \\
\hline Labour & $\begin{array}{l}\text { Labour in terms of the number of annual working units } \\
\text { (AWU) on the farm (SE010) }\end{array}$ & AWU & Positive \\
\hline Land & $\begin{array}{l}\text { Land is presented in the number of hectares (ha) of utilised } \\
\text { agricultural area (UAA) (SE025) }\end{array}$ & $\mathrm{Ha}$ & Positive \\
\hline $\begin{array}{l}\text { Intermediate } \\
\text { Consumption }\end{array}$ & $\begin{array}{l}\text { Total specific costs (including inputs produced on the } \\
\text { holding) and overheads arising from production in the } \\
\text { accounting year. = Specific costs }+ \text { Overheads (SE275) }\end{array}$ & EUR & Positive \\
\hline
\end{tabular}

Note: definition according to EC (2018)

Table 3: Exogenous variables in the inefficiency effect model and definitions

\begin{tabular}{|c|c|}
\hline Variables (vector $\mathrm{z}$ ) & Definition \\
\hline $\mathrm{Z}_{1}$ :Age & Age in years \\
\hline Z2: Subsidy composition & $\begin{array}{l}\text { Share of subsidies in total output }(\%) \text { (the ratio of total subsidies } \\
\text { received by the farms to their total output }\end{array}$ \\
\hline Z3: Share of Crop Output to Total Output & $\begin{array}{l}\text { This variable serves as a proxy for specialization and is measures as } \\
\text { the Ratio of crop production in total production }(\%)\end{array}$ \\
\hline Z4: Total Land to Total Labour ratio & Ratio of total land to total labour (\%) \\
\hline Z5: Hired labour to total labour & Share of Hired Labour to Total Labour (\%) \\
\hline Z6: rented land & Ratio of rented land to total utilised land (\%) \\
\hline Z7: Debt ratio & Ratio of total debts to total assets $(\%)$ \\
\hline Z8: DumReg & $\begin{array}{l}1 \text { for farms in Rrafshi } \mathrm{i} \text { Kosoves and } 0 \text { for otherwise (Rrafshi } \mathrm{i} \\
\text { Dukagjinit) }\end{array}$ \\
\hline Z9: DumLegal & $\begin{array}{l}\text { a legal form dummy, taking the value } 1 \text { if the farm is a company, and } \\
0 \text { otherwise (family) }\end{array}$ \\
\hline
\end{tabular}




\section{RESULTS AND DISCUSSION}

The descriptive statistics of output, inputs and other exogenous variables for 394 farms in sample are shown in Table 4. On average, a farm in Kosovo produces output with a value of 17,675 Euros by using 2.59 AWU of labour, 99.02 ha of land, 294 thousand Euros of assets and more than 6 thousand euros of variable input.

Results of estimated production function (Table 5) suggest that the classical inputs together with the variable input are all statistically significant at $1 \%$ significance level. The signs of the input coefficients are as expected for labour, land and variables input. For the labour variable input, a $1 \%$ increase in labour input (AWU) increases the output for $0.46 \%$, a $1 \%$ increase in total utilized area (UAA) increase the output by $0.12 \%$ and a $1 \%$ increase in intermediate consumption increases the output by $0.66 \%$. The capital input, however, is found to have negative impact on output. Its interpretation is that for $1 \%$ increase in capital, the output is decreased by $0.46 \%$. This negative impact can be due to outdated technology. Effect of total subsidies is negative but insignificant.

Table 4 Descriptive statistics of variables

\begin{tabular}{|c|c|c|c|c|c|}
\hline Variable & Obs & Mean & Std. Dev & Min & Max \\
\hline Y-Output (€) & 394 & $17,675.03$ & $23,486.49$ & 1,100 & 343,150 \\
\hline L-Labour (AWU) & 394 & 2.59 & 2.50 & 0.22 & 22.91 \\
\hline C-Capital $(€)$ & 394 & $294,389.60$ & $555,877.60$ & 50 & $7,137,800$ \\
\hline H- Land (ha) & 394 & 99.02 & $1,336.19$ & 0.1 & 24,125 \\
\hline VI-Intermediate Consumption $(€)$ & 394 & $6,882.32$ & $37,102.43$ & 250 & 698,350 \\
\hline $\mathrm{Z}_{1}$ :Age & 392 & 52.78 & 13.03 & 0 & 85 \\
\hline Z2:Share of Total Subsidies to Total Output & 394 & 6.93 & 40.92 & 0 & 770.46 \\
\hline Z3:Share of Crop Output to Total Output & 394 & 52.66 & 25.03 & 0 & 100 \\
\hline Z4:Share of Total Land to Total Labour & 394 & 565.12 & 800.82 & 4.93 & 8,550 \\
\hline Z5:Share of Hired Labour to Total Labour & 394 & 18.42 & 246.67 & 0 & 4,223 \\
\hline Z6:Share of Rented Land to Total UAA & 394 & 61.78 & 251.80 & 0 & 3,400 \\
\hline Z7:Share of Total Liabilities to Total Assets & 394 & 0.16 & 0.97 & 0 & 9.96 \\
\hline Z8:DumReg & 394 & 0.59 & 0.49 & 0 & 1 \\
\hline Z9:DumLegal & 394 & 0.97 & 0.16 & 0 & 1 \\
\hline
\end{tabular}

Source: Own computation based on FADN MAFRD (2014) data

Table 5 Results of the SFA model: production function and the inefficiency effect model

\begin{tabular}{lllll}
\hline Ly & MLE Coeff. & Std. Err. & Z & P>|z| \\
\hline Frontier & & & & \\
Ln Capital *** & -0.46583 & 0.0013 & -350.00 & 0.000 \\
Ln Labour*** & 0.460707 & 0.0031 & 150.00 & 0.000 \\
Ln Land*** & 0.120963 & 0.0018 & 68.00 & 0.000 \\
Ln Variable Input*** & 0.663622 & 0.0014 & 480.00 & 0.000 \\
_cons & 11.42037 & & & \\
Usigmas & & & & \\
Z1:Age & -0.00343 & 0.0058187 & -0.59 & 0.555 \\
Z2: Share of Total Subsidies to Total Output & 0.00332 & 0.0041406 & 0.80 & 0.423 \\
Z3: Share of Crop Output to Total Output & 0.004538 & 0.0030089 & 1.51 & 0.131 \\
Z4: Share for Total Land to Total Labour** & -0.00021 & 0.0000897 & -2.36 & 0.018 \\
Z5: Share of Hired Labour to Total Labour** & 0.000727 & 0.0003332 & 2.18 & 0.029 \\
Z6: Share of Rented Land to Total UAA & 0.000182 & 0.000288 & 0.63 & 0.526 \\
Z7: Share of Total Liabilities to Total Assets & 0.035166 & 0.0711658 & 0.49 & 0.621 \\
Z8: DumReg * & 0.248634 & 0.1492074 & 1.67 & 0.096 \\
Z9: DumLegal & 0.056056 & 0.4520715 & 0.12 & 0.901 \\
cons & 1.506596 & 0.5817548 & 2.59 & 0.01 \\
Vsigmas & & & & \\
_cons & -39.3687 & 1382.505 & -0.03 & 0.977 \\
\hline Note:
\end{tabular}

Note: $* * *, * * *$ significance at $10 \%, 5 \%$ and $1 \%$ significance level respectively.

Source: Own computation based on FADN MAFRD (2014) data

Table 6 Technical efficiency scores from the model with the firm specific variables

\begin{tabular}{llllll}
\hline Variable & Obs. & Mean & Std. Dev. & Min & Max \\
\hline Technical Efficiency Scores & 394 & 0.156971 & 0.160575 & 0.00025 & 0.9999 \\
\hline
\end{tabular}

Source: Own computation based on FADN MAFRD (2014) data 


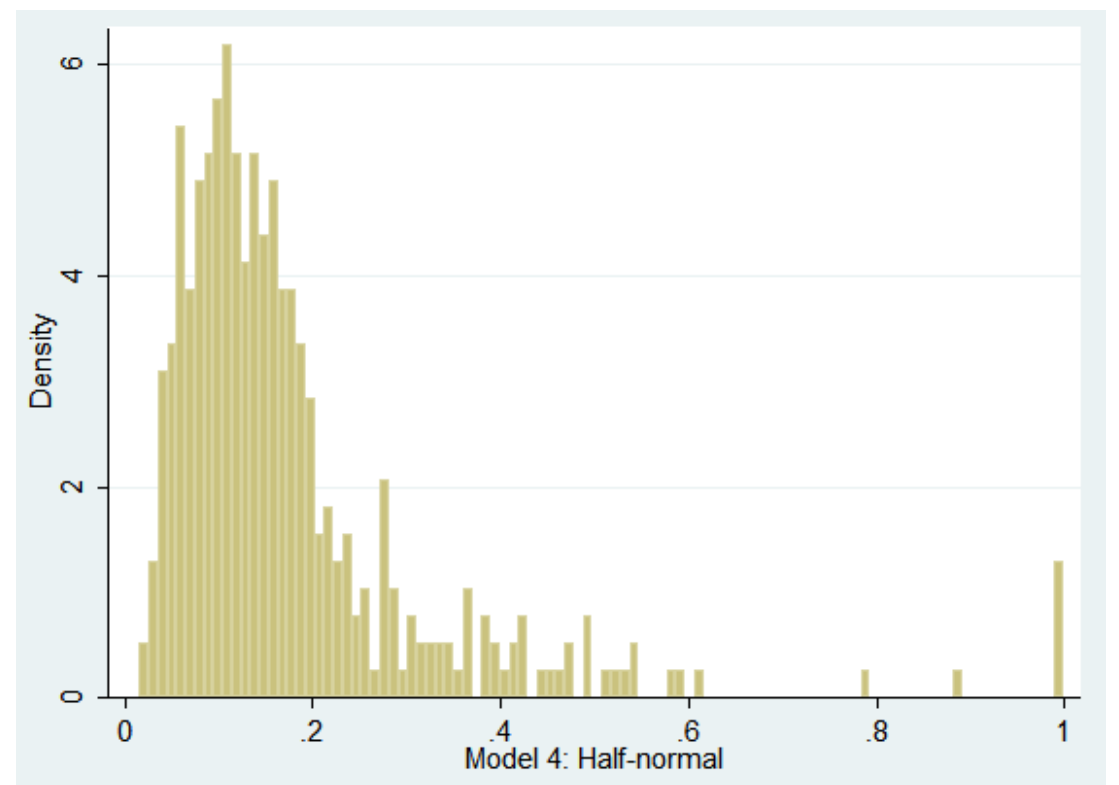

Figure 1. Histogram of efficiency score of the Half-Normal model with exogenous variables Source: Own computation based on FADN MAFRD (2014) data

The calculated technical efficiency scores for 2014 are very low (Table 6). Technical efficiency score indicates that on average a farm produced $15.7 \%$ of the maximum output. This low level of efficiency means that the rest of the potential output, $84.3 \%$, was lost due to technical inefficiency.

The histogram of the efficiency score demonstrates clearly the level of efficiency of the Kosovo farms. Majority of the farm efficiency score range between 0 and 0.2 (Figure 1).

The results of the analysis of technical efficiency for farms in Kosovo in 2014 suggest, that the technical efficiency scores were very low. For the estimation of technical efficiency, it has been assumed that producers produce one single output from multiple inputs. They produce one output either because they actually do produce a single output or because they are able to aggregate their multiple outputs into a single output index. We considered that the farmer produced one output through the use of three classical inputs (capital, labour and land) and one variable input (intermediate consumption). All the inputs were expected to have positive and significant effect on output. The results suggest that for the case of Kosovo all the input variables were significant at $1 \%$ significance level and have the expected positive sign except the variable of capital which has the negative sign. The negative sign of capital was found also by Latruffe at al. (2004) on the case of the Polish farms, which was explained by less productive old machinery in the countries with economy in transition. Since also Kosovo is a transition country and still in the developing stages, this negative sign of capital is due to the old technologies used by the farmers. Another reason for the negative sign found in our study for capital, may be overestimation of the capital by the farmers. Instead of declaring the real value of capital, the farmers in Kosovo overestimated this value.
Regarding the inefficiency model, the share of total land to total labour positively affect the efficiency scores. The variable which presents the share of hired labour to total labour affects negatively the technical efficiency score. Both the mentioned variables are significant at 5\% significance level. Also the variable of region is significant, indicating that farm in the region of Kosovo are less efficient than farms in the region of Dukagjini.

Public support, given in the form of direct payments or as rural development measure, during the last decades has gained lot of attention because of the effect that they have on the performance of the farm. Limitations of our study steam from availability of cross-session data for one year 2014, while the SFA techniques requires more observations, preferable panel data. In addition, the sample of 394 farms represents only $0.6 \%$ of total farm population in Kosovo, therefore the analysis of the results should be treated with caution due to insufficient representation of farms according to economic size.

\section{CONCLUSIONS}

The farm average technical efficiency in transition economies is $86 \%$ whereas in Kosovo is only $15.7 \%$, indicating that an average farmer in Kosovo produces 68.3 less percentage points of the potential output than an average farms in transition countries. Regarding the inefficiency model, is can be suggested that total subsidies to total output as a proxy for supporting policies has negative effect but is not significant. The findings of this paper suggest that efficiency scores for the case of Kosovo are very low and as such the Kosovar government should assist farmers to promote the production process by providing technical assistance and research and development activities, rather than providing subsidies without any kind of criteria and target.

Even though the empirical result on the performance of the farms in Kosovo is not promising, it is the first study 
to measure farm efficiency by implementing SFA methodology on cross-sectional data. As a result, the investigation of efficiency on Kosovo farms in this study is primarily of substantial policy relevance because contributes to better policy making. On the other hand, it is believed that in the near future when the FADN datasets will be available also for the other years and with more variables, it will be possible to create panel data sets and as such to have more realistic results regarding the technical efficiency scores.

\section{REFERENCES}

ASD. AGRICULTURAL STATISTICS DATABASE KOSOVO. (2016), Agricultural statistics database compiled for Kosovo under SWG Project. Retrieved from Agricultural Statistics Database- KOSOVO: http://app.seerural.org/agricultural-statistics/

BATTESE, G. E., \& COELLI, T. J. (1995). A Model for Technical Inefficiency Effects in a Stochastic Frontier Production Function for Panel Data. Empirical Economics, 20, 325-332. DOI: 10.1007/BF01205442

BATTESE, G. E., \& BROCA, S. S. (1997). Functional Forms of Stochastic Frontier Production Functions and Models for Technical Inefficiency Effects: A Comparative Study for Wheat Farmers in Pakistan. JPA, 8(4), 395-414. DOI: 10.1023/A:1007736025686

BERGSTRÖM, F. (2000), "Capital subsidies and the performance of firms", Small Business Economics 14(3):183-193. DOI: 10.1023/A:1008133217594

BOJNEC, S., \& LATRUFFE, L. (2009). Determinants of technical efficiency of Slovenian Farms. Post-Communist Economies, 21(1), 117-124. DOI: 10.1080/14631370802663737

BRÜMMER, B. (2001). Estimating confidence intervals for technical efficiency: the case of private farms in Slovenia. European Review of Agricultural Economics, 28(3), 285-306. DOI: $10.1093 / \mathrm{erae} / 28.3 .285$

COELLI, T.J. (1996). FRONTIER Version 4.1. AUSTRALIA: Centre for Efficiency and Productivity Analysis, University of Queensland.

COELLI, T. J., RAO, D. P., O'DONNELL, C. J., \& BATTESE, G. E. (2005). An introduction to efficiency and productivity analysis (2nd Ed.). USA: Springer. DOI: $\underline{10.1007 / \mathrm{b} 136381}$

EC (2018). European Commission. Farm Accountancy Data Network. Definition of variables. http://ec.europa.eu/agriculture/rica/definitions en.cfm

FADN MAFRD (2014). FADN of Kosovo, Ministry of Agriculture, Forestry and Rural Development

GIANNAKAS, K., SCHONEY, R. \& TZOUVELEKAS, V. (2001). Technical efficiency, technological change and output growth of wheat farms in Saskatchewan. Canadian Journal of Agricultural Economics, 49(2), 135-152. DOI: 10.1111/j.1744-7976.2001.tb00295.x

GIANNAKAS, K., TRAN, K., \& TZOUVELEKAS, V. (2003). On the choice of functional form in stochastic frontier modelling. Empirical Economics, 28, 75-100. DOI: $10.1007 / \mathrm{s} 001810100120$

HARRIS, R., \& TRAINOR, M. (2005). Capital subsidies and their impact on total factor productivity: Firm-level evidence from Northern Ireland, Journal of Regional
Science, 45(1):49-74. DOI: $\quad 10.1111 / \mathrm{j} .0022-$ 4146.2005.00364.X

KALIRAJAN, K. (1991). The importance of efficient use in the adoption of technology: A micro panel data analysis. Journal of Productivity Analysis, 2(2), 113-126. DOI: https://doi.org/10.1007/BF00156342

KAS. (2014). Agricultural Census. Prishtina: Kosovo Agency of Statistics.

KEROLLI-MUSTAFA, M., \& GJOKAJ, E. (2016). Kosovo: Agricultural Policy Development and Assessment. Prishtina: Joint Research Center and SWG.

KROUPOVÁ, Z., \& MALÝ, M. (2010). Analýza nástrojů zemědělské dotační politiky - aplikace produkčních funkcí, Politická ekonomie, 58(6): 774-794.

KOO, W., \& KENNEDY, P. (2006). The Impact of Agricultural Subsidies on Global Welfare. American Journal of Agricultural Economics, 88(5), 1219-1226. DOI: $10.1111 /$ j. 1467-8276.2006.00936.x

KOOPMANS, T. C. (1951). An Analysis of Productions an Efficient Combination of Activities. In T. C. Koopmans, Ed., Activity Analysis of Production and Allocation. New York: Cowles Commission for Research in Economics, Monograph No. 13, Willey.

KUMBHAKAR, S., \& LOVELL, C. (2000). Stochastic Frontier Analysis. Cambridge UK: Cambridge University Press. DOI: 10.1017/CBO9781139174411.

KUMBHAKAR, S. C. (1990). Production Frontiers, Panel Data and Time-Varying Technical Inefficiency. Journal of Econometrics, 46, 201-212. DOI: 10.1016/0304$\underline{\text { 4076(90)90055-X }}$

KUMBHAKAR, S., WANG, H., \& HORNCASTLE, A. (2015). A Practitioner's Guide to Stochastic Frontier Analysis Using Stata. Cambridge: Cambridge University Press. DOI: 10.1017/CBO9781139342070

LATRUFFE, L., \& FOGARASI, J. (2009). Farm performance and support in Central and Western Europe: A comparison of Hungary and France. Working Papers SMART - LERECO 09-07, INRA UMR SMARTLERECO.

LATRUFFE, L., BALCOMBE, K., \& DAVIDOVA, S. (2008). Productivity change and Polish agriculture: An application of a bootstrap procedure to Malmquist indices. Post-Communist Economies, 20, 449-460. DOI: https://doi.org/10.1080/14631370802444708

LATRUFFE, L., BALCOMBE, K., DAVIDOVA, S., \& ZAWALINSKA, K. (2004). Determinants of technical efficiency of crop and livestock farms in Poland. Applied Economics, 36(12), 1255-1263. DOI: $\underline{10.1080 / 0003684042000176793}$

MAFRD (2015). Green Report 2015. Prishtina: The Ministry of Agriculture Forestry and Rural Development. MAFRD (2016). Green Report 2016. Prishtina: The Ministry of Agriculture Forestry and Rural Development. MAFRD (2017). Green Report 2017. Prishtina: The Ministry of Agriculture Forestry and Rural Development. MATHIJS, E. \& VRANKEN, L. (2001). Human Capital, Gender and Organisation in Transition Agriculture: Measuring and Explaining the Technical Efficiency of Bulgarian and Hungarian Farms. Post-Communist Economies, 13(2), 171-187. DOI: $\frac{10.1080 / 14631370120052654}{\text { RAY }}$

RAY, S. (1988). Data envelopment analysis 
nondiscretionary inputs and efficiency: an alternative interpretation. Socio-Economic Planning Science, 22, 167-176. DOI: $\quad$ https://doi.org/10.1016/00380121(88)90003-1

REZITIS, A., TSIBOUKAS, K., \& TSOUKALAS, S. (2003). Investigation of factors influencing the technical efficiency of agricultural producers participating in farm credit programs: The case of Greece. Journal of Agricultural and Applied Economics, 35(3), 529-541. DOI: $10.1017 /$ S1074070800028261

VOZAROVA, I., \& KOTULIC, R. (2016). Quantification of the effect of subsidies on the production performance of the Slovak agriculture. Procedia Economics and Finance, 39, 298 - 304. DOI: 10.1016/S2212$\underline{5671(16) 30327-6}$

SWAIN, S. (2009). Trade Externalities of Agricultural Subsidies and World Trade Organization. American Journal of Economics and Business Administration, 1(3), 225-231.
ZHU, X., DEMETER, R. M., \& LANSINK, A. O. (2008). Competitiveness of dairy farms in three countries: the role of CAP subsidies. International EAAE Congress 26-29 August, 2008. Ghent: Belgium.

ZHU, X., \& LANSINK, A. O. (2008). Technical Efficiency of the Crop Farms under the Various CAP Reforms: Empirical Studies of Germany, the Netherlands and Sweden. Paper Presentation at "Modelling Agricultural and Rural Development Policies", 107th European Association of Agricultural Economists (EAAE) Seminar January 29th - February 1st, 2008. Seville, Spain. 